\title{
Multiple Myelomada Otolog Periferik Kök Hücre Nakli Sonrası Lenalidomid Deneyimlerimiz
}

\author{
${ }^{1}$ Neslihan Andıç, ${ }^{2}$ Vildan Özkocaman, ${ }^{3}$ Elif Birtaş Ateşoğlu, ${ }^{2}$ Fahir Özkalemkaş, \\ ${ }^{3}$ Ayfer Gedük, ${ }^{1}$ Olga Meltem Akay \\ ${ }^{1}$ Osmangazi Üniversitesi Tıp Fakültesi, Hematoloji Bilim Dalı, Eskişehir. \\ ${ }^{2}$ Uludağ Üniversitesi Tıp Fakültesi, Hematoloji Bilim Dalı, Bursa. \\ ${ }^{3}$ Kocaeli Üniversitesi Tıp Fakültesi, Hematoloji Bilim Dalı, Kocaeli. \\ e-posta: neslihandic@yahoo.com
}

\begin{abstract}
ÖZET: Multipl miyelom nükslerle seyreden, tam iyileşmenin günümüzde mümkün olmadığı bir hastalıktır. Otolog periferik kök hücre nakli (OPKHN) olmuş hastalarda, hastalık nüksünde lenalidomid uygun bir tedavi seçeneği olarak karşımıza çıkmaktadır. Osmangazi Üniversitesi, Uludağ Üniversitesi, Kocaeli Üniversitesi Tip Fakülteleri Hematoloji Bilim Dallarında OPKHN olmuş ve ardından hastalığı relaps olmuş 52 multipl myelom hastasının verileri incelenmiștir. Kısmi ve daha iyi yanıt elde edilen hastaların oranı $\% 45.5$ dir. Sitopeniler ve halsizlik en stk görülen yan etkiler olarak karşımıza çıkmaktadır. Diyare genel literatürde beklenenden daha sık olarak tedavi kesilmesine yol açmıştır. Tüm sonuçlar incelendiğinde rezistan ve yoğun tedaviler almış bir hasta grubunda da lenalidomidin etkin ve kolay tolere edilebilir bir ilaç olduğunu görmekteyiz.
\end{abstract}

ANAHTAR KELIMMELER: kök hücre nakli, lenalidomid, multipl myelom.

SUMMARY: Multiple myeloma is characterised with frequent relapses and is considered as incurable in todays medicine. Lenalidomide is a suitable treatment option for relapses after autologous peripheral stem cell transplantation (APSCT). 52 multiple myeloma patients who were followed in Osmangazi University, Uludağ University and Kocaeli University School of Medicine Hematology Departments and relapsed after APSCT were examined. Percentage of patients who achieved partial response or better was $45.5 \%$. Cytopenias and fatique were the most frequent side effects. Treatment cessation because of diarrhera was more frequent than reported in the literature. All results considered, even in a resistant and heavily treated patient group lenalidomide is an efficient and easily tolerated medication.

KEY WORDS: stem cell transplantation, lenalidomide, multiple myeloma

\section{Giriş}

Multipl miyelom, tüm kanserlerin \%1'ni ve hematolojik kanserlerin \%10'unu oluşturmaktadır (1,2). Tam iyileşme günümüzde henüz mümkün değildir ancak tedavilerle uzun süreli remisyonlar elde edilebilmektedir. Multipl miyelomda indüksiyon tedavisinin ardından kök hücre toplanarak otolog periferik kök hücre nakli (OPKHN) yapılması, tedavinin standart bir parçası haline gelmiştir $(1,2)$. OPKHN remisyonu uzattığı iyi bilinen bir tedavi metodu olsa da hemen hemen tüm miyelom hastaları sonunda nüks olurlar. Hastalığı nakil sonrası nüks hastalıkta lenalidomid uygun bir seçenek olarak karşımıza çıkmaktadır $(3,4)$.Lenalidomid, oral yolla kullanılan, immün-düzenleyici bir ilaçtır. Tümor kitlesinde hızlı bir azalma sağlamakla beraber proliferasyonu önlediği ve uzamış hastalık kontrolü sağladığı gösterilmiştir (5). Nakil sonrası en azından çok iyi kısmi yanıt (ÇİKY) elde edilememiş hastalarda lanelidomid ile idame yapılması da öneriler arasındadır (4). Ancak bu endikasyonda ülkemizde geri ödemesi bulunmamaktadır. Nakil sonras1 relaps hastalarda ise 2 yıla kadar kullanımı onaylanmıştır. Nüks hastalıkta lenalidomid ve deksametazonun deksametazona üstünlüğünü gösteren iki 
geniş faz III çalışma mevcuttur $(5,6)$. En s1k ve önemli yan etkiler nötropeni ve trombositopenidir. Kreatinin klirensine göre doz ayarlaması yapılması gerekmektedir. Daha önceden yoğun tedaviler almış hastalardaki etkinliği ve güvenirliği ile ilgili Türkiye verilerine ihtiyaç bulunmaktadır. Çalışmamızın amacı OPKHN sonrası nüks hastalıkta lenalidomidin etkinliği ve yan etkileri ile ilgili Türkiye verilerine katkıda bulunmaktır.

\section{Gereç ve Yöntemler}

Bursa Uludağ Üniversitesi Tıp Fakültesi, Eskişehir Osmangazi Üniversitesi Tıp Fakültesi ve Kocaeli Üniversitesi Tıp Fakültesi Hematoloji Kliniklerinde takip edilmekte olan multipl miyelom hastas1, OPKHN sonrası lenalidomid kullanmıs, 52 hastanın verileri retrospektif olarak değerlendirildi. Hastalar son 5 yıl içerisinde üç üniversite hastanesine başvuran ardışık lenalidomid almış hastalard1. Yanit oranları, 2006'da miyelom çalışma grubu tarafından yayınlanan kriterler esas alınarak belirlendi (7).

\section{Bulgular}

Hastaların 36's1 kadın (\%69), 16's1 erkekti $(\% 31)$. Ortalama yaş $52 \pm 8$ olarak bulundu. 31'i (\%60.8) IgG, 10’u (\%19.6) IgA ve 10'u da hafif zincir tipi miyelomdu. Hastaların 6's1 (\%12.2) Durie Salmon'a göre evre I, 18'i (\%36.7) evre II, 25'i (\%51) evre III'dü. Genetik sonuçlarından 10'u (\%58.8) normal, dördü (\%23.5) 13q delesyonu, ikisi (\%11.8) kompleks karyotip ve biri (\%5.9) hiperdiploidi olarak raporlanmıştı. 1 hasta hariç tüm hastalar VAD kemoterapisini ilk basamak tedavi olarak kullanmışlardı. 24 hasta $(\% 46)$ sadece VAD ile OPKHN'ne hazırlanmışlardı. 28 hastaya $(\% 53.8)$ bortezomib, 5 hastaya (\%9.6) thalidomid, 6 hastaya lenalidomid içeren kemoterapi rejimleri uygulanmıştı. 8 hastaya $(\% 15)$ nakil öncesi 3 ve daha fazla basamak tedavi uygulamak gerekmişti. Hastalar median 6 kür (en az 3 en fazla 17) tedavi ile nakile hazırlanmışlardı. Hastalar, nakil sonrası median 12 ayda relaps olmuşlardı. Aldıkları lenalidomid kür sayılarının ortancası 4 (quartiles (2-6.5))' dü. En az 1 en fazla $21 \mathrm{doz}$ tedavi almışlardı. 38 hasta (\%73.1) lenalidomid ve lenalidomid dexametazon tedavisi almış, 8 hasta (\%21.6) lenalidomid yanı sira bortezomib, 10 hasta (\%27) lenalidomid yanı sıra siklofosfamid kullanmıştı. Lenalidomid, $25 \mathrm{mg} /$ gün, 21 gün boyunca hastalara verildi. Kreatinin klirensine ve gelişen yan etkilere göre ürün monogramında önerilen şeklide doz azaltımları yapıldı. Lenalidomid tedavi sonuçları ile ilgili bilgiler tablo1'de görülmektedir. Ex olan 5 hastadan 2'si progresif hastalık nedeniyle 2 kür den az tedavi almışken, 1 'i tedavinin dördüncü gününde akut böbrek yetmezliği ile 2'si pnömoni nedeniyle kaybedildi. Lenalidomid tedavisi sirasinda 10 hastada yan etkiler nedeniyle tedavi kesilmek zorunda kalındı. 4 hastada doz azaltımı yapıldı. Yan etkiler tablo 2 de özetlenmiştir. Hastaların nakil sonrası izlem süreleri ortalama 22.4 ay $( \pm 16.4) \quad$ idi. 
Tablo 1.

Lenalidomid tedavisi sonuçları

\begin{tabular}{lcc}
\hline Değişkenler & $\mathrm{n}$ & $\%$ \\
\hline Tam yanıt & 12 & $\% 11.4$ \\
Çok iyi kısmi yanıt & 8 & $\% 18.2$ \\
Kısmi yanıt & 7 & $\% 15.9$ \\
Stabil hastalık & 4 & $\% 9.1$ \\
Progresif hastalık & 8 & $\% 18.2$ \\
Ex & 5 & - \\
2.OPKHN yapılan hastalar & 13 & $\% 25$ \\
Allogenik nakil yapılan hasta & 1 & - \\
\hline
\end{tabular}

Tablo 2.

Lenalidomid tedavisi sırasında görülen yan etkiler

\begin{tabular}{lccc}
\hline Değişkenler & $\begin{array}{c}\text { Yan etki izlenen } \\
\text { hasta sayısı }\end{array}$ & $\begin{array}{c}\text { Yan etki nedeniyle tedavisi } \\
\text { kesilen hasta sayısı }\end{array}$ & $\begin{array}{c}\text { Toplam } \\
\%\end{array}$ \\
\hline Sitopeniler & 16 & 3 & 36 \\
Halsizlik & 12 & 3 & 23 \\
Enfeksiyon & 8 & 7 & 21 \\
Diyare & 3 & & 13 \\
Döküntü & & 1 & 5.7 \\
Baş ağrısı & & 1 & 1.9 \\
Derin ven trombozu/ & & & \\
pulmoner emboli & & & \\
\hline
\end{tabular}




\section{Tartışma}

Lenalidomid ikinci jenerasyon immündüzenleyici ve pek çok antikanser etkileri olan bir ilaçtır (8). Literatürde relaps hastalarda lenalidomid dexametazon ile \%60 civarı kısmi veya daha iyi yanıt oranları bildirilmektedir $(5,6)$. Bizim çalışmamızda bu oran \% 45.5 olarak bulunmuştur. Çalışmamızda cevap oranın daha düşük çıkma sebebi bu hastaların diğer çalışmalardan daha yoğun tedavi almış ve tümünün nakil sonrası nüks olmuş hastalar olması olabilir. Yan etki profiline bakıldığında hastalarımızda literatürde bildirilenler ile aynı oranda sitopeni, halsizlik ve enfeksiyona yatkınlık olduğunu görüyoruz. Yan etkiler nedeniyle tedavi kesilme oranı Weber ve ark. tarafından \%19 olarak bildirilmiștir (6). $\mathrm{Bu}$ oran bizim çalışmamızda \%28 olarak gözükmektedir. Lenalidomid dexametazon alan sadece bir hastada trombüs izlenmiştir. $\mathrm{Bu}$ oran literatürde bildirilenden \%11-\%14 oranından daha azdır. Nedeni hastaların rutin ASA proflaksisi kullanmış olması olabilir. Diyare sıklığı genel olarak bildirilenden fazla değildir ancak diyare nedeniyle ilaç kesilme oranı literatürde bildirilen ciddi diyare oranından (\% $1.7-3)$ oldukça fazladır. Halkımızın diyareyi tolere etme eșiği yabancı kaynaklardan farklı olabilir. En sik gözlenen yan etki literatürde de olduğu gibi nötropenidir ancak tedavi kesilmesi genellikle gerekmemektedir. Sonuç olarak, lenalidomid uygulama kolaylığı ve yönetilebilir yan etki profili ile relaps multipl miyelom hastalarında tercih edilebilecek ve uzun süre kullanılabilecek etkin bir ajandır.

\section{KAYNAKLAR}

1. Rajkumar, S.V.(2011). Treatment of multiple myeloma. Nature Rev Clin Oncol.8:479-491

2. Rajkumar, S.V. Gahrton, G. Bergsagel, P.L. (2011).Approach to the treatment of multiple myeloma: A clash of philosophies. Blood. 118:3205-3211.

3. McCarthy, P.L. Owzar, K. Hofmeister, C. et al. (2012). Lenalidomide after Stem Cell Transplantation for Multiple Myeloma. $N$ Engl J Med. 366:17701781

4. Rajkumar, S.V. (2014). Multiple myeloma: update on diagnosis, risk stratification and management. Am J Hematol. 89:999-1009.
5. Dimopoulos, M. Spencer, A. Attal, M. et al. (2007). Lenalidomide plus dexamethasone for relapsed or refractory multiple myeloma. $N$ Engl $J$ Med. 357:2123-2132

6. Weber, D.M. Chen, C. Niesvizky, R. et al. (2007). Lenalidomide plus dexamethasone for relapsed multiple myeloma in North America. $N$ Engl $J$ Med. 357:2133-2142

7. Durie, B.G. Harousseau, J.L. Miguel, J.S. et al. (2006). International Myeloma Working Group. International uniform response criteria for multiple myeloma. Leukemia. 20:1467-1473 